\title{
ENVIRONMENTAL AND WITHIN-NEST FACTORS INFLUENCING NESTLING-FEEDING PATTERNS OF MEDITERRANEAN BLUE TITS (CYANISTES CAERULEUS)
}

\author{
Vicente García-Navas ${ }^{1}$ and Juan José Sanz \\ Área de Zoología, Facultad de Ciencias Ambientales y Bioquímica, Universidad de Castilla-La Mancha, \\ Avenida Carlos III s/ $n$ 45071, Toledo, Spain
}

\begin{abstract}
The rate at which parent birds deliver food to their young may depend on several factors, both intrinsic (e.g., brood demand) and extrinsic (e.g., time of day). Using PIT tags, we determined patterns of nestling provisioning in the Blue Tit (Cyanistes caeruleus) and the proximate factors affecting them. Over 3 years, we monitored the rates of provisioning by Blue Tits in two types of forest (evergreen and deciduous) in Cabañeros National Park (Spain). Pairs breeding in the deciduous forest visited the nest at rates higher than did those in the evergreen forest. Contrary to expectation, males fed their offspring more than females did, and the rates of feeding were positively related to those of the social partner. Sex roles in provisioning were consistent through the day, suggesting that parents did not work in concert. Provisioning rates also tended to decline through the day and were negatively correlated with ambient temperature. In females, but not in males, the adult's body condition was negatively related to provisioning effort. There was no relationship between nestlings' condition and parental provisioning rates. We found a strong correlation between hourly feeding rates and the total number of feedings registered over a 24-hr period, which indicates that short-term samples are representative of what occurs over a longer time. Overall, our study represents a significant contribution to the understanding of proximate factors influencing parental provisioning strategies in altricial birds with biparental care.
\end{abstract}

Key words: diurnal variation, feeding rates, nestling provisioning, parental care, RFID, transponder.

Factores Ambientales y Sociales que Influyen en los Patrones de Aprovisionamiento de las Crías de Cyanistes caeruleus

Resumen. La frecuencia con la cual las aves proporcionan alimento a sus crías puede depender de varios factores, tanto intrínsecos (e.g., demanda de la nidada) como extrínsecos (e.g., hora del día). Aquí, nosotros determinamos los patrones de aprovisionamiento de Cyanistes caeruleus y los factores próximos que los determinan mediante el uso de microchips. Durante un período de estudio de 3 años, seguimos las tasas de aprovisionamiento de C. caeruleus en dos tipos de bosque (un hábitat esclerófilo y otro deciduo) dentro del Parque Nacional de Cabañeros (España central). Las parejas que crían en el bosque deciduo visitaron el nido a tasas más elevadas que aquellas que lo hicieron en el bosque esclerófilo. En contra de lo esperado, los machos alimentaron a su descendencia con mayor frecuencia que las hembras y sus tasas de alimentación se relacionaron positivamente con las de su pareja. El papel de los sexos en el aprovisionamiento de los polluelos fue consistente durante el transcurso del día, sugiriendo que los padres no realizan dicha labor de forma coordinada. Las tasas de aprovisionamiento tendieron a disminuir con el progreso de la jornada y se relacionaron de forma negativa con la temperatura ambiente. En las hembras, pero no así en los machos, la condición corporal de los adultos se relacionó negativamente con el esfuerzo de aprovisionamiento. No hubo relación entre la condición de los polluelos y las tasas de aprovisionamiento de los padres. Finalmente, encontramos una fuerte correlación entre las tasas de alimentación horarias y el número total de visitas al nido registrado durante un periodo de 24 horas, lo cual indica que las muestras a corto plazo son representativas de lo que ocurre en un periodo de tiempo más largo. En conjunto, nuestro estudio supone una contribución significativa al conocimiento de los factores próximos que influyen en las estrategias de aprovisionamiento de los padres en aves altriciales con cuidado biparental.

\section{INTRODUCTION}

During brood rearing, parent birds allocate most of their time and resources to the care of the young (Clutton-Brock 1991). Parental-investment theory (Trivers 1972) predicts that the willingness of parents to invest in parental care should be influenced by the relative value of the current offspring and the parents' future prospects of reproducing. According to Trivers (1972), parental investment can be defined as "any contribution that increases the success of the current progeny at the

Manuscript received 30 July 2011; accepted 8 February 2012.

${ }^{1}$ E-mail: vicente.garcianavas@uclm.es

The Condor, Vol. 114, Number 3, pages 612-621. ISSN 0010-5422, electronic ISSN 1938-5422. @ 2012 by The Cooper Ornithological Society. All rights reserved. Please direct all requests for permission to photocopy or reproduce article content through the University of California Press's Rights and Permissions website, http://www.ucpressjournals.com/ reprintInfo.asp. DOI: 10.1525/cond.2012.110120 
expense of a parent's ability to reproduce in the future." Since it is not plausible (or at the very least, difficult) to quantify the parents' decrease in future reproduction, parental investment can arguably be quantified only indirectly through measures that are thought to be related to the actual costs. Nestlingprovisioning rates are often used as a surrogate measure of parental care (see Møller and Thornhill 1998 and references therein). The frequency with which altricial birds feed their young has been the subject of a large body of research, primarily focused on the social (e.g., chick age) and environmental (e.g., prey density) factors that determine the level of parental provisioning.

With regard to life-history factors, a common finding in these studies is that provisioning rates tend to increase linearly with brood size (Gibb 1955, Royama 1966). However, above a certain level, parents may be unwilling to increase their food delivery in proportion to the increase in the number of chicks, as revealed by experiments in which brood size is manipuled (e.g., Nur 1984, Wright and Cuthill 1990). According to the model of optimal feeding frequency proposed by Nur (1984) parents should optimize their investment in their young by weighing the fitness benefits (to progeny) and costs (to parents) of an increase in feeding frequency. As a result of this trade-off, the level of food provisioning per nestling should decline as brood size increases, reflecting parents' priority for ensuring their own, rather than their offspring's, survival when confronted with a high demand from nestlings (i.e., larger-than-average sized broods; see Rytkönen et al. 1996, Laiolo et al. 1998).

The contribution of each sex to parental care may also affect overall feeding rates. In general, females invest more heavily than do males, but the intensity of females' vs. males' parental effort is highly variable among and within species (Davies 1991). The relative investment that each sex makes in provisioning young has been shown to be related to several factors such as the male's certainty of paternity (Sheldon 2002), division of parental duties (Bańbura et al. 2001), and the partner's contribution (e.g., Ardia 2007). In relation to the last, there is controversy over the mechanism by which males and females respond to each other's level of effort. In "negotiation" models (McNamara et al. 1999, Johnstone and Hinde 2006), an individual is expected to adjust its parental investment directly in response to the partner's effort. In contrast, some authors (Houston and Davies 1985, Schwagmeyer et al. 2002) have proposed that individuals behave as if they had committed to a fixed level of effort at the outset, not modifying their parental investment when the partner's contribution is altered.

At a nest, provisioning rates may vary with time of day (e.g., Cowie and Hinsley 1988). Among insectivorous birds, a common pattern is one of a high level of activity in the early morning, a decrease during midday, and a slight increase in the late afternoon (e.g., Knapton 1984). The midday lull in feeding activity may be the result of the unavailability of nonflying insects such as larvae of Lepidoptera (the most important food for many Passeriformes) during the warmer hours (Hutto 1981) and/or the effect of midday heat stress on foraging adults (Tinbergen and Verhulst 2000). In the Mediterranean region, where the spring and summer are usually hot and dry, maximum temperatures should be more limiting for adult birds when provisioning their young than should minimum temperatures (Nager and Wiersma 1996). This contrasts with results reported in northern latitudes, where low temperatures require parents to spend more time brooding at the nest, therefore decreasing their feeding frequency (Pravosudov and Pravosudova 1996, Siikamäki 1996, Wiebe and Elchuk 2003).

Last, habitat quality mirrored in prey density and quality, as well as in the distribution of these across the birds' feeding range, may also have an influence on the frequency with which parents deliver food to their offspring (Bańbura et al. 1994, Naef-Daenzer et al. 2000, Stauss et al. 2005). Recent studies in the northern temperate region have revealed that the Great Tit (Parus major) and Pied Flycatcher (Ficedula hypoleuca) feed their chicks more frequently in deciduous habitats than in coniferous habitats (Mägi et al. 2009, Sisask et al. 2010). Meanwhile, studies on the island of Corsica found that Blue Tits (Cyanistes caeruleus) breeding in sclerophyllous forests (regarded as habitats "poorer" than deciduous forests) traveled farther in search of food and provisioned their young at lower rates, but with larger prey, than did those settled in rich deciduous oak forests (Blondel et al. 1991, Tremblay et al. 2005).

This study is focused on the parental provisioning behavior of the Blue Tit, a socially monogamous passerine with biparental care. Over 3 years, we monitored the provisioning patterns of Blue Tits breeding in evergreen and deciduous forests in central Spain, southern Europe. We examined intrinsic and extrinsic factors that influence individual variation in provisioning rates. We also tested for the existence of sexual differences in the Blue Tit's provisioning behavior (number of visits, duration of the working day) and how parents vary their provisioning effort through the day (i.e., daily patterns of feeding). We then explored whether variation in feeding frequencies were related to phenotypic traits (size, body mass) of the parents and the effect of parental provisioning rates on offspring condition.

\section{METHODS}

\section{STUDY AREA}

The study was carried out in Cabañeros National Park (Ciudad Real and Toledo provinces, central Spain, $39^{\circ} 24^{\prime} \mathrm{N}, 3^{\circ} 35^{\prime} \mathrm{W}$ ) during three consecutive breeding seasons (2006-2008). The park comprises a wide diversity of vegetation types: (1) extensive grass cover dotted with dispersed trees (holm oak, Quercus rotundifolia; cork oak, Q. suber), (2) siliceous Mediterranean forest dominated by Pyrenean oak ( $Q$. pyrenaica), strawberry tree (Arbutus unedo), and Spanish heather (Erica australis) and (3) scrublands composed mainly of gum cistus 
(Cistus ladanifer) and tree heather (E. arborea). The climate is Mediterranean-continental, characterized by hot and dry summers and fairly low temperatures in winter. In May (when most birds rear their young), average temperature and precipitation are $16.4{ }^{\circ} \mathrm{C}$ and $43 \mathrm{~mm}$, respectively. We chose two of the predominant habitats in the park for the location of our study plots: a deciduous forest ("El Brezoso") located along a riverbank and dominated by Pyrenean oaks, and an evergreen forest ("Anchurones") located in a floodplain and composed of holm and cork oaks scattered in a savanna-like configuration. The two plots stand at a distance of approximately $2 \mathrm{~km}$ from each other. In total, 250 wooden nest boxes, attached to tree trunks at heights of 2.0-2.5 m, were distributed over the two study plots (Anchurones, 150; El Brezoso, 100). Nest boxes were protected from predators (mustelids, woodpeckers) with wire mesh and a polyvinyl chloride (PVC) pipe fixed through the hole's entrance. The density of breeding pairs per hectare was higher in the deciduous forest $\left(5.7 \mathrm{ha}^{-1}\right)$ than in the sclerophyllous evergreen forest $\left(3.7 \mathrm{ha}^{-1}\right)$.

\section{GENERAL FIELD METHODS}

We surveyed nest boxes daily from early April to the end of June to obtain basic measures of reproduction such as the onset of egg laying, clutch size, length of the incubation period, hatching success, and breeding success (i.e., number of fledglings divided by the number of eggs). By means of spring traps, we captured parents at nest boxes when their chicks were 8 days old. We determined the sex and age of each parent by the presence/absence of a brood patch and plumage characteristics (Svensson 1992), respectively. We measured the tarsus length (to the nearest $0.01 \mathrm{~mm}$ with digital calipers) and body mass (to the nearest $0.1 \mathrm{~g}$ with a pocket balance) of all trapped birds ( $95 \%$ of males, $98 \%$ of females). Parents were marked with aluminum bands, and most of them (91 males and 96 females) were equipped with a passive integrated transponder (PIT) tag (see below). At day 13, we banded and measured nestlings similarly. We excluded replacement clutches and broods depredated (by ants or snakes) from the original data set. Dates are numbered as $1=1$ April.

\section{MONITORING PARENTAL EFFORT}

We used frequency of feeding as an indicator of the parents' activity. We fitted both members of a pair with a microtransponder (Trovan ID 103, length $11.6 \mathrm{~mm}$, mass 0.1g, Trovan Ltd., Douglas, UK) glued to two plastic bands and wrapped with a piece of black duct tape. In the presence of an electromagnetic field, these microchips produce a unique amplitudemodulated code signal, providing individual identification of each bird (for more details on PIT tags see Nicolaus et al. 2008). Upon capture (day 8), we substituted the front of the nest box with another one with an antenna embedded within the PVC tube and connected to a data-logging module placed on the ground. In this way, we recorded the time at which a bird entered or left the nest. From these recordings, following a procedure similar to that of Johnsen et al. (2005), we extracted feeding rates. We found a strong correlation between parental feeding rates estimated with videotape recording and those obtained by means of this system (García-Navas et al. 2009). The similarity of the two sets of estimates shows that the PIT-tag method resulted in realistic estimates of provisioning effort. We recorded feeding activity for $48 \mathrm{hr}$. Here, we report data corresponding to the last $24 \mathrm{hr}$ (day 10 after hatching) in order to ensure that feeding activity was not influenced by human disturbances during the installation of the nestmonitoring system. Sampled broods hatched from 21 April to 5 June (range, 2006: 26-56; 2007: 25-66; 2008: 21-54).

A total of 112 pairs were equipped with transponders but because of transponder loss, desertion/disappearance of one member of a pair, or missing data for some hours as a consequence of a logger breaking down, we obtained complete data from 76 pairs (23 in 2006, 28 in 2007, 25 in 2008). Some individuals were captured more than once (11 males and 10 females recorded in 2 years; 2 males and 2 females recorded in 3 years), but in each case the bred again with the same partner as in the previous year. Because mean brood size on day 8 at the two sites differed (mean \pm SE, Anchurones: $7.30 \pm 0.36$, El Brezoso: $6.31 \pm 0.27 ; F_{1,106}=4.8, P=0.03$ ) we employed feeding rates per chick as an estimate of parental feeding effort. WE used overall feeding rates (total number of visits per day) when examining the effect of nestling demand (brood size at day 8) on provisioning behavior. Mean date of hatching differed significantly by year (mean $\pm \mathrm{SE}, 2006: 37.24 \pm 1.5$, 2007: 39.97 $\left.\pm 1.4,2008: 32.25 \pm 1.3 ; F_{2,105}=8.7, P<0.001\right)$ but not between study plots (mean \pm SE, Anchurones: $35.94 \pm 1.4$, El Brezoso: $36.17 \pm 1.1 ; F_{1,106}=0.1, P=0.58$ ).

The vast majority of studies of parental feeding rates are based on short-term samples (1-2 hr) under the assumption that these estimates are representative of the overall number of visits to the nest by parents over the course of a day. However, we are not aware of any study in which this has been tested. We used linear regressions between hourly feeding rates (from 07:00 to 20:00) and the total number of visits to the nest to test if short-term samples constitute a good estimate of the daily total amount of effort that parents devote to feed their offspring.

\section{TEMPERATURE DATA}

We recorded maximum, minimum, and average ambient temperature on day 10 after hatching by means of four Tinytags (Gemini Data Loggers, West Sussex, UK) installed inside empty nest boxes that were dispersed throughout the study plots. Tinytags recorded the ambient temperature $\left({ }^{\circ} \mathrm{C}\right)$ at 5 min-intervals from April through June.

\section{DATA ANALYSES}

We used general linear models (GLM) to analyze the influences of study year, site (evergreen vs. deciduous forest), date (i.e., seasonal variation or calendar effect), brood size (number of 
nestlings present at the time of sampling), and ambient temperature (mean, maximum and minimum on day 10 after hatching) on frequencies of parents' feeding. In a first step, we tested whether differences in local conditions (e.g., ambient temperature) have an effect on the birds' patterns of provisioning. We then investigated sex-specific differences in parental provisioning, comparing males' and females' feeding rates by means of Student's $t$-tests. We also employed paired $t$-tests to explore whether the relative contribution of each sex to the provisioning of offspring varied through the day. In a further step, we split the day into three time blocks (morning, 07:00-11:00; midday, 12:00-16:00, afternoon, 17:00-20:00) to determine at which time of day rates of Blue Tits' provisioning were higher. When feeding nestlings, parents usually start their visits by sunrise and finish close to sunset (Hinde 1952). We analyzed whether both members of the pair initiate/finish their feeding activity at the same time or if the sexes' working hours differ, calculating the time from the first visit to the nest to the last. We also analyzed how the amount of time devoted to feeding the offspring varies through the season, taking into account the number of daylight hours available for feeding (i.e., the length of the photoperiod, see Sanz et al. 2000). We calculated times of sunset and sunrise for each date with the program Suncycle (http:// users.telenet.be/suncycle). All times are reported in Spanish summer time (GMT $+2 \mathrm{hr}$ ). In subsequent analyses, using the variance-components module of Statistica 6 (StatSoft, Inc., Tulsa, OK) we studied whether individual variation in feeding rates was related to breeding experience (age) and phenotypic traits of the parents. We accounted for potential effects of relevant environmental and individual variables: year of study, forest type, brood size, time of season, and body size. To avoid pseudoreplication, we included the bird's identity as a random factor. Finally, we examined whether variation in provisioning rates (total feeding rates) had an effect on the offsprings' condition (mean body mass and size).

The models we present are the final results obtained by a backward deletion procedure: we removed variables from the starting model when the variance explained did not significantly improve the model. Proportions and percentages were square-root-transformed to approximate normality. Means \pm standard error are reported unless otherwise specified.

\section{RESULTS}

\section{YEAR AND SITE EFFECTS ON PROVISIONING RATES}

Daily feeding rates per chick differed significantly by year (2006: $38.27 \pm 3.4,2007: 91.27 \pm 6.8,2008: 58.64 \pm 2.5$; $\left.F_{2,72}=30.5, P<0.001\right)$ and between the two sites $\left(F_{1,72}=5.9\right.$, $\mathrm{P}=0.02)$. Blue Tits provisioned their young at a higher rate in the deciduous forest (Anchurones: $54.43 \pm 5.5$, El Brezoso: $71.07 \pm 4.9$ feedings per chick). There was no habitat $\times$ year interaction $\left(F_{2,70}=0.1, \mathrm{P}=0.99\right)$. The difference between sites was of approximately the same order of magnitude over the
3 years (Anchurones, 2006: $30.7 \pm 7.7,2007: 82.2 \pm 7.7,2008$ : 64.1 \pm 6.3 ; El Brezoso, 2006: 44.1 \pm 6.7, 2007: $96.3 \pm 7.7,2008$ : $64.1 \pm 6.3$ feedings per chick).

Regarding other potential factors that may contribute to the existence of annual variability and site-dependent effects on provisioning frequency, we observed that average ambient temperature differed significantly by year (2006: $20.19 \pm 0.5$, 2007: $\left.16.60 \pm 0.5 ; 2008: 13.64 \pm 0.4, F_{2,105}=45.1, P<0.001\right)$ but not by site (Anchurones: $17.44 \pm 0.4$, El Brezoso: $16.56 \pm$ $\left.0.3 ; F_{1,102}=2.6, P=0.11\right)$.

Neither year nor habitat type had a significant influence on the reproductive output (in terms of breeding success) of Blue Tits (all $P>0.25$ ). Nestlings' condition varied by year (2006: $9.89 \pm 0.1 \mathrm{~g}, 2007: 10.11 \pm 0.1 \mathrm{~g}, 2008: 9.99 \pm 0.1 \mathrm{~g}$; $\left.F_{2,67}=5.7, P<0.01\right)$ and differed significantly at the two sites $\left(F_{1,67}=5.2, P=0.03\right)$, mean nestling mass being $10.02 \pm 0.1 \mathrm{~g}$ at Anchurones and $9.97 \pm 0.1 \mathrm{~g}$ at El Brezoso.

\section{SEX DIFFERENCES AND EFFECTS OF BROOD SIZE ON PROVISIONING RATES}

The overall number of visits made by the parents increased linearly with brood size (year: $F_{2,72}=63.7, P<0.001$, brood size: $\left.b=33.5, F_{1,72}=33.0, P<0.001\right)$, but the adults were unable to increase their level of parental effort in proportion to the increment in brood size. Daily feeding rates per chick declined as brood size increased (year: $F_{2,72}=57.2, P<0.001$, brood size: $\left.b=-7.1, F_{1,89}=47.8, P<0.001\right)$. There was no seasonal trend in provisioning frequency in either study year (2006: $F_{1,21}=0.1, P=0.70 ; 2007: F_{1,26}=0.4, P=0.55 ; 2008$ : $F_{1,23}=0.4, P=0.51$ ).

The contribution of each sex to chick provisioning did not differ by site ( $\operatorname{sex} \times$ habitat: $F_{2,74}=0.4, P=0.70$ ). Therefore, when analyzing differences between the sexes in the Blue Tit's provisioning behavior, we pooled data from both study plots. Males' and females' rates of feeding differed significantly; females fed their young less frequently than did males (feeding visits per chick, males: $37.26 \pm 20.2$, females: $27.24 \pm 17.5 ; t=4.7, n=76, P<0.001)$. This pattern was remarkably constant; the number of visits by males was significantly higher than that of females for almost the entire day (Fig. 1). Within a pair, the male's and the female's provisioning effort were strongly correlated (Pearson's correlation, $r=0.53, n=76, P<0.001$ ).

\section{DAILY PATTERNS AND ENVIRONMENTAL FACTORS}

The rate of parental visits to the nest varied by time of day (hours from 07:00 to 20:00 grouped by 3 intervals of $5 \mathrm{hr}$ ) ( $t$-test, morning vs. midday; males: $t=11.0, P<0.001$, females: $t=4.4, P<0.001$, midday vs. afternoon; males: $t=$ $-1.2, P=0.21$, females: $t=-3.1, P<0.01)$. The general pattern in males was a high activity level immediately after dawn followed by a notable decrease in the subsequent hours until midday, at which point the number of visits remained almost constant (Fig. 1). The activity of females peaked in the early 


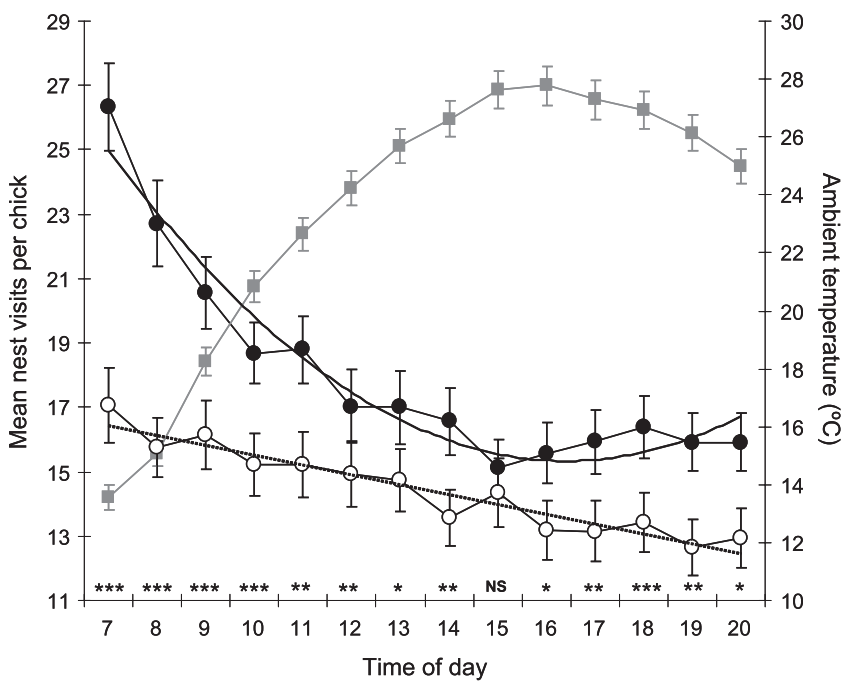

FIGURE 1. Pattern of Blue Tits' visits to the nest (means \pm SE, filled dots and solid line, males; empty dots and dotted line, females) and daily fluctuation in temperature (means $\pm \mathrm{SE}$, squares and gray line) by hour of the day. Asterisks indicate significant differences between sexes for each interval (pairwise comparisons, $n=76 ; * * * P<0.001 ; * * P<0.01 ; * P<0.05$; NS, $P>0.05)$.

morning, but the pattern of visits did not reach a plateau, instead decreasing irregularly until the end of the day (Fig. 1). The difference between the sexes' provisioning rates was maximal early in the morning (07:00-09:00). During our study, sunrise ranged from 06:21 to 06:48, sunset from 20:40 to 21:09. Females started to feed their young earlier (females, mean: 06:57, males, mean: 07:04; $t=4.6, n=76, P<0.001$ ) and ended later (females, mean: 21:24, males, mean: 21:04; $t=8.6, n=76, P<0.001)$ than males, which explains the difference between the sexes in hours worked (females: $14 \mathrm{hr} 26$ min, males: 13 hr 59 min; $t=8.6, n=76, P<0.001)$. The amount of time devoted to feeding the nestlings increased through the season (Fig. 2, males: $r=0.45, P<0.001$; females: $r=0.42, P<0.001)$.

There was a strong correlation between hourly feeding rates and the total number of feedings registered over a 24-hr period (daily feeding rates) in both sexes and at any given time of day (all Pearson's coefficients $>0.80$, all $P<0.001$; Fig. 3).

Daily feeding rates per chick were negatively correlated with mean (year: $F_{2,72}=26.9, P<0.001$, mean temperature: $b=-2.7, F_{1,72}=8.35, P<0.01$ ) and maximum (year: $F_{2,72}=$ 26.3, $P<0.001$, maximum temperature $b=-1.8, F_{1,72}=6.4$, $P=0.01)$ temperatures but not with minimum temperatures (year: $F_{2,72}=26.9, P<0.001$, minimum temperature: $F_{1,72}=$ $1.4, P=0.24)$. Analyses of covariance showed that the interaction term between sex and ambient temperature was not significant $\left(F_{1,173}=0.5, P=0.48\right)$, indicating that the slopes of the respective regressions did not differ (Fig. 4). That is, one

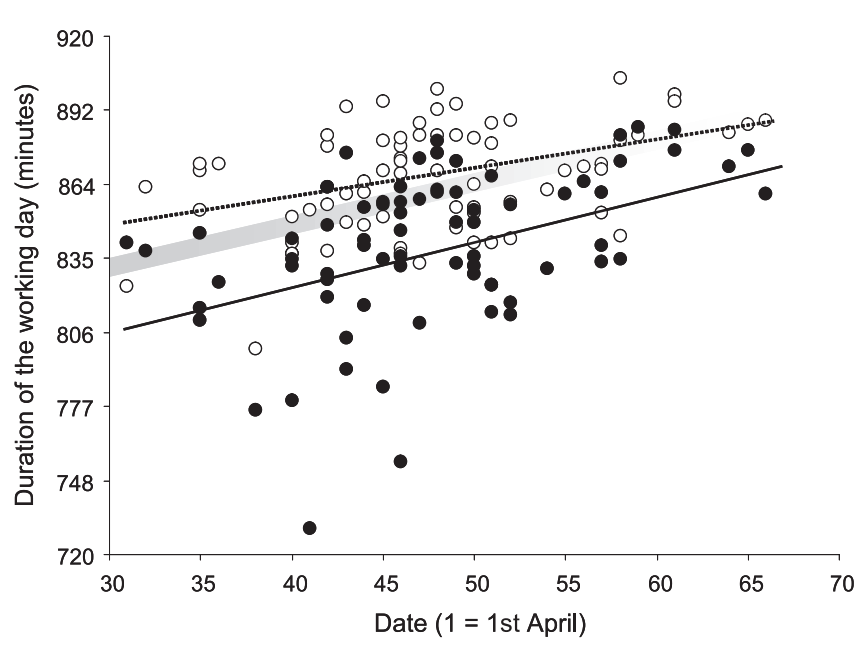

FIGURE 2. Mean time between Blue Tits' first and last visits to the nest each day, by date. The gray band indicates the seasonal variation of photoperiod (daylight hours) in the study area in central Spain. Filled dots and solid line, males; empty dots and dotted line, females.

sex was not more temperature-dependent than the other with respect to its provisioning frequency.

\section{PARENTAL CHARACTERISTICS AND EFFECTS OF PROVISIONING FREQUENCY ON NESTLING CONDITION}

Finally, we evaluated the effect of the parents' morphological characteristics on their provisioning rates. We accounted for

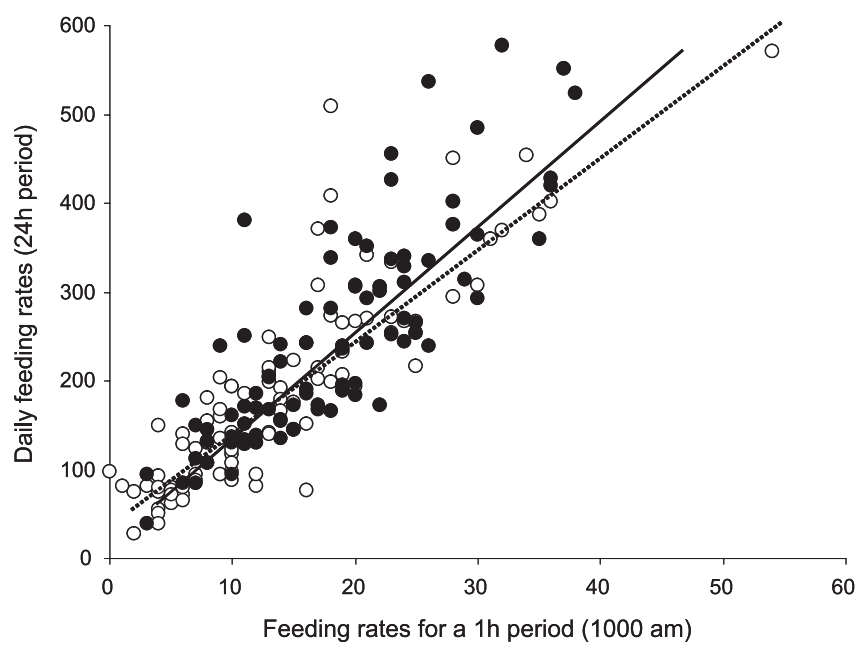

FIGURE 3. Linear regression between feeding rates per chick for a 1-hr period (10:00-11:00) and the total number of feedings detected over a $24-\mathrm{hr}$ period (daily feeding rate). Filled dots and solid line, males; empty dots and dotted line, females. 


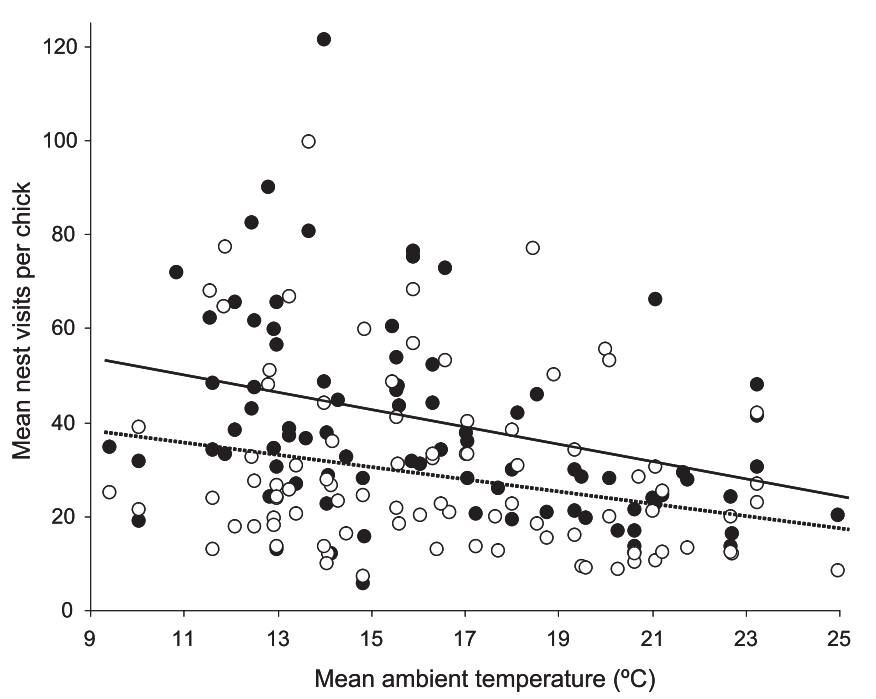

FIGURE 4. Mean number of visits per chick made by male and female Blue Tits in relation to ambient temperature on day 10 after hatching in Cabañeros National Park, Spain. Filled dots and solid line, males; empty dots and dotted line, females.

the effects of habitat type, study year, and brood size because these factors explained a significant part of variation in provisioning effort (see above). The results indicated that younger females fed their young at rates lower than did older females (first-year breeders: $27.39 \pm 2.3$, older: $30.95 \pm 3.1, F_{1,84}=$ $8.7, P<0.01)$ and that females' body mass was negatively related to their provisioning frequency $\left(b=-7.0, F_{1,84}=4.0, P=\right.$ 0.048 ); heavier females fed nestlings less often that did lighter females (Fig. 5). Females' size (tarsus length) had no influence on their provisioning frequency $\left(F_{1,83}=1.2, P=0.28\right)$. We found no significant relationships between either age, size, or body mass and the males' feeding rates (all $P$ values $>0.5$ ).

Nestlings' body mass was positively correlated with their tarsus length $\left(b=0.9, F_{1,67}=5.7, P=0.02\right)$. Measurements of nestlings were not related to the frequency of their parents' provisioning (mass: $F_{1,67}=1.1, P=0.30$, tarsus length: $F_{1,67}=$ $0.5, P=0.49)$.

\section{DISCUSSION}

\section{YEAR AND SITE EFFECTS}

The Blue Tit's rates of provisioning differed significantly by year, being much lower in 2006 than in the other two years. The difference could partially be explained by the large variation in weather conditions from one year to another. The 2006 breeding season was characterized by excessively high temperatures (May was the warmest of the last decade with temperatures reaching $\left.36^{\circ} \mathrm{C}\right)$ and low rainfall $(30.3 \mathrm{~mm}$ in May), whereas the last two springs were wetter (2007: 76.7, 2008: $74.3 \mathrm{~mm}$ ) with milder temperatures.

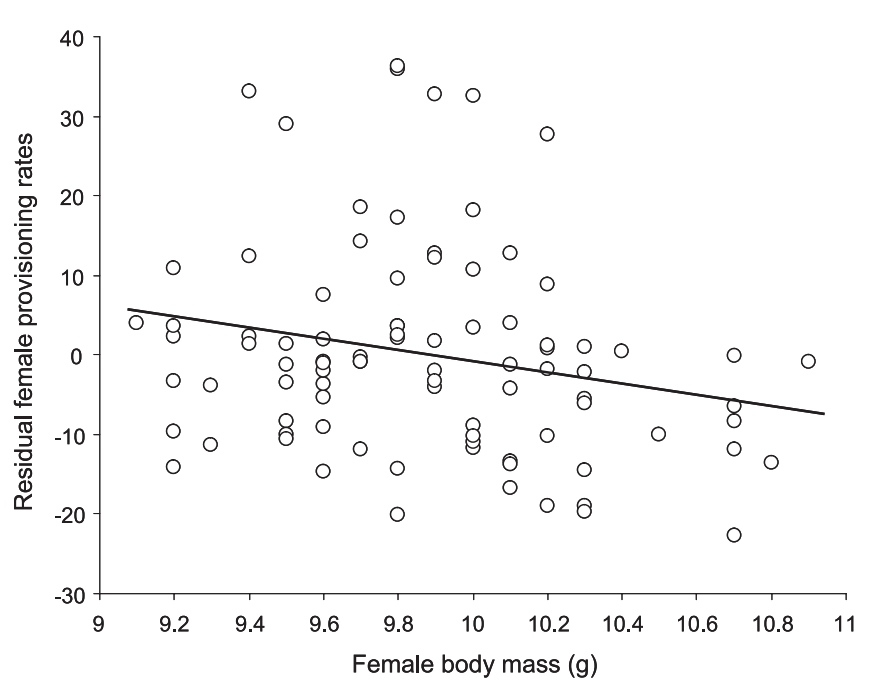

FIGURE 5. Rates of females' provisioning (number of visits per chick) plotted against their body mass after control for other influencing variables: year of study, brood size, and the female's age.

Parents provisioned their young more frequently in the deciduous habitat than in the sclerophyllous, which is in agreement with previous studies that have shown clear habitat-related differences in the Blue Tit's provisioning rates on Corsica (Blondel et al. 1991, Tremblay et al. 2005). Blondel et al. $(1991,1993)$ hypothesized the discrepancy to be related to differences in the timing and abundance of food resources (caterpillar peak) between distinct types of oak habitat (richdeciduous vs. poor-evergreen,). Blondel (2007) also suggested such site-specific differences in food supply as the main factor responsible for the differences between the two forest types in measures of breeding (e.g., smaller clutch sizes in evergreen habitats). In our study we did not find evidence that pairs breeding in the holm oak forest did worse (in terms of breeding success or offspring condition) than those settled in the deciduous habitat. In this sense, Díaz and Pulido (1993) found no relationship between the density of the Blue Tit and food abundance in holm oak forests of southwest Spain; they reported that arthropod abundance in the oak canopies was greater than the birds' estimated requirements. Thus there is no a priori reason for these sclerophyllous forests (the Iberian dehesas, see Tellería 2001) to be considered suboptimal habitats for this species. The higher frequency of feeding we observed in the holm oak forest could be related to differences between the sites in prey type. Preliminary data suggest that the percentage of caterpillars brought to the nest may be similar in both forests (Anchurones: $69.32 \pm 6.6, n=12$; El Brezoso: $67.60 \pm 2.6, n=12, P=0.63)$, although we also found that the percentage of large caterpillars (noctuids) in the nestlings' diet was higher in the evergreen forest (Anchurones: 
$55.42 \pm 7.5$; El Brezoso: $32.86 \pm 14.6, n=12, P<0.01$; GarcíaNavas et al., unpubl. data). Therefore, further studies including both feeding rates and diet information (prey quality) are necessary for a better understanding of the determinants of parental-effort decisions, especially when different forest types are compared, as we did.

\section{SEX DIFFERENCES AND EFFECTS OF BROOD SIZE}

The number of feeding trips per brood increased and the number of feeding trips per chick decreased with brood size. That is, the increase in provisioning rates to large broods was apparently insufficient for the increased food demand, resulting in fewer visits per chick in larger broods, in agreement with previous studies (e.g., Nur 1984, Rytkönen et al. 1996). Nonetheless, we have recently shown that in terms of parental effort Blue Tits are able to respond in the short term (from one day to the next) to daily manipulations of brood size (García-Navas and Sanz 2010). We found that parents provisioning enlarged broods increased the number of visits but at the expense of effort in searching (i.e., being less selective in prey choice, García-Navas and Sanz 2010). This supports the notion that parents are unwilling to increase their level of investment in a brook above a certain threshold, even though they may be able to do so (e.g., Barba et al. 2009).

Trends in the sexes' provisioning were consistent over the course of the day (see more below), which suggests that parents do not work in concert (i.e., they did not complement each other) as predicted by models based on negotiation rules. Trivers (1972) suggested that females should invest more in provisioning young because of their investment in the early phases of reproduction (egg laying, incubation). Contrary to expectations, we found that female Blue Tits provisioned their young less frequently than did their mates, contributing $42 \%$ of the feedings within a pair. Males always took primary responsibility for feeding nestlings, which has been scarcely reported among monogamous birds (Grundel 1987, Stodola et al. 2009). The causes and consequences of the sexes' different roles during provisioning is a matter of further research. On one hand, our findings are at odds with some theoretical approaches (e.g., Winkler 1987), in which the conflict of interest between the sexes is viewed as an evolutionary tug-of-war between the male and female over the level of parental investment (each parent preferring that the other provide more care), resulting in an inverse relationship in the sexes' effort. Within a pair, we found a positive correlation between the male's and female's feeding frequencies. This result could equally well be the outcome of mutual mate assessment based on the partner's condition (each member of the pair contributing a sealed-bid level of effort according to its condition) or the outcome of negotiation during courtship (Schwagmeyer et al. 2002). On the other hand, Clotfelter et al. (2007) interpreted a similar result as the common response of the pair to variation in factors that influence provisioning effort (e.g., food availability, nestling demand). Another possibility is that such a relationship arises as a consequence of the assortative mating of high-quality birds. In the populations of the Blue Tit we have studied, we have found the heterozygosity of social mates to be positively correlated, suggesting that this species may select mates on the basis of the partner's heterozygosity (García-Navas et al. 2009). In addition, in males, we observed a positive association between an individual's genetic diversity and feeding rates. Therefore, it is plausible that mate-choice decisions may be behind the observed trend.

\section{DAILY PATTERNS AND ENVIRONMENTAL FACTORS}

The sexes' diurnal routines of nest visitation were quite similar: in both cases visitation peaked in the morning, then declined through the day. This pattern is in agreement with that reported by Cowie and Hinsley (1988) in a previous study on provisioning effort in the Blue Tit. Males' provisioning rates tended to remain stable after midday, whereas females' rates diminished steadily, in a linear fashion (Fig. 3), which suggests that the costs and strategies determining provisioning routines differed by sex. The sexual difference in provisioning effort remained constant except for the first hours of the day, when males' feeding rates were higher (Fig. 3). Males and females also differed significantly in the duration of their working day; females started provisioning earlier and ended later than did males. One possible explanation of this result is sexual differences in the birds' night-time behavior. For instance, females evidently roost in their nest boxes during the breeding period whereas males do not (Cramp 1998, pers. obs.). Thus it seems that females' behavioral patterns were more precisely adaptive, while males apparently did not use time as well as their partners.

Within each year, frequency of feeding was negatively correlated with ambient temperature; the number of feeding trips per chick declined as temperatures increased. Tinbergen and Verhulst (2000) pointed out that ambient temperature may impose an extrinsic limit to energy expenditure (an "energetic ceiling") in small birds. Thus it is likely that in warm environments like those of the Mediterranean basin, parents are compelled to feed their young less frequently as a result of increased foraging costs. Such trade-offs could be especially important during the central hours of the day when temperatures are higher (Fig. 2). Daily temperature fluctuations and their physiological effect on foraging adults could serve to explain the observed diurnal variation in provisioning frequencies, especially in males, whose pattern of nest visitation was inversely related to ambient temperature (an exact mirror image, see Fig. 2). The fact that feeding rates were highest in the early morning, when prey activity is still limited, suggests that the effect of ambient temperature is more related to thermoregulatory problems than to low food availability. In other words, coping with heat stress (increased cost of flight, need for dissipating the radiational heat load) is the most 
plausible explanation for the decrease in provisioning during midday. Thus our results contrast with those for other species whose nest-visitation rates are positively associated with increasing ambient temperature, as predicted by the temperaturedependent food-availability hypothesis (see Low et al. 2008 and references therein). Finally, another plausible explanation is that the reduction observed during the middle part of the day may be due to the high rate of provisioning in the early morning hours because chicks went 8-9 hours without being fed.

On the other hand, we found a strong correlation between hourly feeding rates and the provisioning effort of parents over a 24-hr period (see Fig. 3). We chose 10:00 to illustrate such a relationship because most studies of provisioning behavior are based on frequencies of feeding during the first hours of daylight, before noon (usually between 08:00 and 11:00). Our results thus indicate that short-term samples (hourly feeding rates) are valid in predicting the total number of feedings over a day.

\section{PARENTAL CHARACTERISTICS AND NESTLING CONDITION}

Next, we examined whether individual variation in frequencies of provisioning was related to aspects of the parents' body condition (ornaments excluded). Adults' size did not predict their level of parental investment during this stage of reproduction. Females' body mass was significantly related to frequency of feeding: the more frequent the feeding, the lower the weight of the female. For males, however, there was no evident relationship between their weight and their frequency of feeding, which coincides with the findings reported by Nur (1984) and Gosler (1991). Since we did not weigh females during incubation or at the beginning of brood rearing, we cannot determine if certain females provisioned their young at higher rates because they were lighter (i.e., a female's weight determines her provisioning capability) or if these females were lighter or lost more weight because they fed their young more often (i.e., a female's weight being the consequence, not the cause). Nur (1984) suggested the second option as the most plausible hypothesis. The so-called "reproductive stress" hypothesis assumes that reproduction is physiologically costly and that changes in body condition during breeding should be interpreted as the result of the energetic demands of this period (Nagy et al. 2007, Neto and Gosler 2010). Nevertheless, we cannot explain why the mass of males did not decrease with increasing frequencies of feeding since males apparently worked harder than their mates.

Finally, we did not find an association between parental provisioning effort and nestlings' condition (e.g., see Nour et al. 1998, Mägi et al. 2009, Wilkin et al. 2009 for similar conclusions). However, we have shown elsewhere that nestlings' mass is strongly related to the relative contribution of tortricid and noctuid larvae to the diet: the higher the proportion of noctuids, the heavier the nestlings (García-Navas and Sanz 2011). Similarly, Schwagmeyer and Mock (2008) failed to find an association between parental deliveries and nestlings' mass, but they found that delivery of the largest food items predicted both the mass and probability of recruitment of nestlings. Thus the utility of measuring parental provisioning without taking into account prey quality could be called into question, as frequent feeding does not always guarantee that chicks are being nourished best (Grieco 2001, Tremblay et al. 2005, Krist 2009, but see Stodola et al. 2010).

One of our main findings was that, contrary to expectation, the apparently poorer habitat offered conditions better than, or at least similar to, those of the ostensibly rich deciduous habitat. This result, and those from mosaics of coniferous and deciduous forests at more northern latitudes (Mägi et al. 2009, Sisask et al. 2010), highlight the risk of extrapolating some rules or well-established assumptions when the response of organisms to environmental heterogeneity is interpreted. Moreover, in contrast to previous studies of the Blue Tit (e.g., Bańbura et al. 2001), we found that males fed nestlings more frequently than did females, and that this pattern remained constant throughout the day. This result emphasizes the importance of considering both sexes' roles when patterns of chick provisioning are analyzed for the sake of a better understanding of the mechanisms underlying them. To conclude, our study shows that short-term samples (hourly feeding rates) are valid in predicting the total number of feedings over a 24-hr period (daily feeding rates), which has implications for ecological studies focused on parental investment and life-history strategies.

\section{ACKNOWLEDGMENTS}

We are grateful to Ángel Gómez-Manzaneque and the rest of the staff of the Cabañeros National Park for the facilities offered to us for research in this nature reserve. We thank Esperanza S. Ferrer for her assistance in trascribing video recordings. We also thank Emma Vatka and Robert L. Curry for constructive comments that improved our manuscript. V.G.-N was supported by a Formación de Personal Investigador fellowship (Ministerio de Ciencia e Innovación-European Social Fund). This study was financially supported by the Organismo Autónomo Parques Nacionales-Ministerio de Medio Ambiente (grant 69/2003) and the Ministerio de Ciencia e Innovación (grant GCL2007-61395).

\section{LITERATURE CITED}

Ardia, D. R. 2007. Site- and sex-level differences in adult feeding behaviour and its consequences to offspring quality in Tree Swallows (Tachycineta bicolor) following brood size manipulation. Canadian Journal of Zoology 85:847-854.

Bańbura, J., J. Blondel, H. DE Wilde-Lambrechts, M.-J. Galan, AND M. Maistre. 1994. Nestling diet variation in an insular Mediterranean population of Blue Tits Parus caeruleus: effects of years, territories and individuals. Oecologia 100:413-420.

Bańbura J., P. Perret, J. Blondel, A. Sauvages, M.-J. Galan, AND M. M. LAmBREChts. 2001. Sex differences in parental care in a Corsican Blue Tit Parus caeruleus population. Ardea 89:517-526. 
Barba, E., F. Atiénzar, M. Marín, J. S. Monrós, And J. A. GilDelgado. 2009. Patterns of nestling provisioning by a singleprey loader bird, Great Tit Parus major. Bird Study 56:187-197.

Blondel, J., A. Dervieux, M. Maistre, And P. Perret. 1991. Feeding ecology and life history variation of the Blue Tit in Mediterranean deciduous and sclerophyllous habitats. Oecologia 88:9-14.

Blondel, J., P. Dias, M. Maistre, And P. Perret. 1993. Habitat heterogeneity and life history variation of Mediterranean tits. Auk 110:511-520.

Blondel, J. 2007. Coping with habitat heterogeneity: the story of Mediterranean Blue Tits. Journal of Ornithology 148 (Suppl. 1):S3-S15.

Clotfelter, E. D., C. R. Chandler, V. Nolan, and E. D. KETTERSON. 2007. The influence of exogenous testosterone on the dynamics of nestling provisioning in Dark-eyed Juncos. Ethology 113:18-25.

Clutton-Brock, T. H. 1991. The evolution of parental care. Princeton University Press, Princeton, NJ.

Cowie, R.J., AND S.A. Hinsley. 1988. Feeding ecology of Great Tits Parus major and Blue Tits Parus caeruleus, breeding in suburban gardens. Journal of Animal Ecology 57:611-626.

Cramp, S. 1998. The complete birds of the western Palearctic. Optimedia, Oxford University Press, Oxford, England.

Davies, N. B. 1991. Mating systems, p. 263-294. In J. R. Krebs and N. B. Davies [EDS.], Behavioural ecology, 3rd ed. Blackwell Science, Oxford, England.

DíAZ, M., AND F. J. Pulido. 1993. Relaciones entre la abundancia de artrópodos y la densidad del Herrerillo Común Parus caeruleus en dehesas durante el período reproductor. Ardeola 40:33-38.

García-Canseco, V. 1997. Parque Nacional de Cabañeros. Ecohábitat, Malagón, Spain.

García-Navas, V., J. Ortego, and J. J. Sanz. 2009. Heterozygosity-based assortative mating in Blue Tits (Cyanistes caeruleus): implications for the evolution of mate choice. Proceedings of the Royal Society B 276:2931-2940.

GARCÍA-NAVAS, V., AND J. J. SANZ. 2010. Flexibility in the provisioning behaviour of Blue Tits in response to short-term manipulations of brood size. Ethology 116:744-754.

García-NAVAS, V., AND J. J. SANZ. 2011. The importance of a main dish: nestling diet and foraging behaviour in Mediterranean Blue Tits in relation to prey phenology. Oecologia 165:639-649.

GRIECO, F. 2001. Foraging and its consequences in the breeding season of the Blue Tit (Parus caeruleus). Ph.D. thesis, University of Utrecht. Ponsen \& Looijen BV, Wageningen, the Netherlands.

GRUNDEL, R. 1987. Determinants of nestling feeding rates and parental invesment in the Mountain Chickadee. Condor 89:319-328.

GIBB, J. 1955. Feeding rates of Great Tits. British Birds 48:49-58.

GosLer, A. G. 1991. On the use of greater covert moult and pectoral muscle as measures of condition in passerines with data for the Great Tit Parus major. Bird Study 38:1-9.

Hinde, R. A. 1952. The behaviour of the Great Tit (Parus major) and some other related species. Behaviour Suppl. 2:1-207.

Houston, A. I., AND N. B. Davies. 1985. The evolution of cooperation and life history in the Dunnock, Prunella modularis, $\mathrm{p}$. 471-487. In R. M. Sibly and R. H. Smith [EDS.], Behavioural ecology: ecological consequences of adaptive behaviour. Blackwell Science, Oxford, England.

HutTo, R. L. 1981. Temporal patterns of foraging activity in some wood warblers in relation to the availability of insect prey. Behavioral Ecology and Sociobiology 9:195-198.

Johnsen, A., K. Delhey, E. Schlicht, A. Peters, and B. KempenAERS. 2005 Male sexual attractiveness and parental effort in Blue Tits: test of the differential allocation hypothesis. Animal Behaviour 70:877-888.
Johnstone, R. A., And C. A. Hinde. 2006 Negotiation over offspring care-how should parents respond to each other's efforts? Behavioral Ecology 17:818-827.

KNAPton, R.W. 1984. Parental feeding of nestling Nashville Warblers: the effects of food type, brood size, nestling age, and time of day. Wilson Bulletin 96:594-602.

KRIST, M. 2009. Short- and long-term effects of egg size and feeding frequency on offspring quality in the Collared Flycatcher (Ficedula albicollis). Journal of Animal Ecology 78:907-918.

Laiolo, P., E. Bignal, And I. J. Patterson. 1998. The dynamics of parental care in Choughs (Pyrrhocorax pyrrhocorax). Journal of Ornithology 139:297-305.

Low, M., S. EgGERs, D. ARLt, AND T. PÄRT. 2008. Daily patterns of nest visits are correlated with ambient temperature in the Northern Wheatear. Journal of Ornithology 149:515-519.

MäGI, M., R. MÄND, H. TAMm, E. SisasK, P. Kilgas, AND V. TIllgar. 2009. Low reproductive success of Great Tits in the preferred habitat: a role of food availability. Écoscience 16:145-157.

McNamara, J. M., C. E. Gasson, And A. I. Houston. 1999. Incorporating rules for responding into evolutionary games. Nature 401:368-371.

Møller, A. P., AND R. Thornhill. 1998. Male parental care, differential parental investment by females and sexual selection. Animal Behaviour 55:1507-1515.

Naef-Daenzer, L., B. Naef-Daenzer, and R. G. Nager. 2000. Prey selection and foraging performance of breeding Great Tits Parus major in relation to food availability. Journal of Avian Biology 31:206-214.

Nager, R. G., And Wiersma, P. 1996. Physiological adjustment to heat in Blue Tit Parus caeruleus nestlings from a Mediterranean habitat. Ardea 84:115-125.

Nagy, L. R., D. Stanculescu, and R. T. Holmes. 2007. Mass loss by breeding female songbirds: food supplementation supports energetic stress hypothesis in Black-throated Blue Warblers. Condor 109:304-311.

Neto, J. M., AND A. G. GosLER. 2010. Variation in body condition of breeding Savi's Warblers Locustella luscinioides: the reproductive stress and flight adaptation hypothesis revisited. Journal of Ornithology 151:201-210.

Nicolaus, M., K. M. Boumman, and N. J. Dingemanse. 2008. Effect of PIT tags on the survival and recruitment of Great Tits Parus major. Ardea 96:286-292.

Nour, N., D. Currie, E. Matthysen, R. Van Damme, and A. A. DHONDT. 1998. Effects of habitat fragmentation on provisioning rates, diet and breeding success in two species of tit (Great Tit and Blue Tit). Oecologia 114:522-530.

Nur, N. 1984. Feeding frequencies of nestling Blue Tits Parus caeruleus: costs, benefits and a model of optimal feeding frequency. Oecologia 65:125-137.

Pravosudov, V. V., And E. V. Pravosudova. 1996. The breeding biology of the Willow Tit in northeastern Siberia. Wilson Bulletin 108:80-98.

RoYAMA, T. 1966. Factors governing feeding rate, food requirement and brood size of nestling Great Tits Parus major. Ibis 108:313-347.

RytKönen, S., K. Koivula, And M. Orell. 1996. Patterns of perbrood and per-offspring provisioning efforts in the Willow Tit Parus montanus. Journal of Avian Biology 27:21-30.

Sanz, J. J., J. M. Tinbergen, J. Moreno, M. Orell, and S. VerHULST. 2000. Latitudinal variation in parental energy expenditure during brood rearing in the Great Tit. Oecologia 122:149-154.

Schwagmeyer, P. L., D. W. Mock, And G. A. Parker. 2002. Biparental care in House Sparrows: negotiation or sealed bid? Behavioral Ecology 13:713-721. 
Schwagmeyer, P. L., AND D. W. Mock. 2008. Parental provisioning and offspring fitness: size matters. Animal Behaviour 75:291-298.

SHELDON, B. C. 2002. Relating paternity to paternal care. Philosophical Transactions of the Royal Society of London B 357:341-350.

SIIKAMÄKI, P. 1996. Nestling growth and mortality of Pied Flycatchers Ficedula hypoleuca in relation to weather and breeding effort. Ibis 138:471-478.

SisAsK, E., R. MÄND, M. MÄGI, AND V. Tilgar. 2010. Parental provisioning behaviour in Pied Flycatchers Ficedula hypoleuca is well adjusted to local conditions in a mosaic of deciduous and coniferous habitat. Bird Study 57:447-457.

Stauss, M. J., J. F. BURKHARDT, AND J. TOMIUK. 2005. Foraging distances as a measure of parental effort in Blue Tits Parus caeruleus differ with environmental conditions. Journal of Avian Biology 36:47-56.

Stodola, K. W., E. T. Linder, D. A. Buehler, K. E. Franzreb, And R. J. COOPER. 2009. Parental care in the multi-brooded Blackthroated Blue Warbler. Condor 111:497-502.

Stodola, K. W., E. T. Linder, D. A. Buehler, K. E. Franzreb, D. H. KIM, AND R. J. COOPER. 2010. Relative influence of male and female care in determining nestling mass in a migratory songbird. Journal of Avian Biology 41:515-522.

SvensSON, L. 1992. Identification guide to European passerines. L. Svensson, Stockholm.

TELLERÍA, J.L. 2001. Passerine bird communities of Iberian dehesas: a review. Animal Biodiversity and Conservation 24:67-78.
Tinbergen, J. M., And S. Verhulst. 2000. A fixed energetic ceiling to parental effort in the Great Tit? Journal of Animal Ecology 69:323-334.

Tremblay, I., D. W. Thomas, M. M. Lambrechts, J. Blondel, And P. Perret. 2003. Variation in Blue Tit breeding performance across gradients in habitat richness. Ecology 84:3033-3043.

Tremblay, I., D. W. Thomas, J. Blondel, P. Perret, and M. M. LAMBRECHTS. 2005. The effect of habitat quality on foraging patterns, provisioning rate and nestling growth in Corsican Blue Tits Parus caeruleus. Ibis 147:17-24.

Trivers, R. L. 1972. Parental investment and sexual selection, p. 136-179. In B. Campbell [ED.] Sexual selection and the descent of man. Aldine, Chicago.

Wiebe, K. L., AND C. L. ElchuK. 2003. Correlates of parental care in Northern Flickers Colaptes auratus: do the sexes contribute equally while provisioning young? Ardea 91:91-101.

WilKIN, T. A., L. E. KING, AND B. C. Sheldon. 2009. Habitat quality, nestling diet and provisioning behaviour in Great Tits. Journal of Avian Biology 40:135-145.

WinkLER, D. W. 1987. A general model for parental care. American Naturalist 130:526-543.

Wright, J., AND I. CuthiLl. 1990. Biparental care: short-term manipulations of partner contribution and brood size in the Starling, Sturnus vulgaris. Behavioral Ecology 1:116-124. 